\title{
TLE2 Gene
}

National Cancer Institute

\section{Source}

National Cancer Institute. TLE2 Gene. NCI Thesaurus. Code C115080.

This gene is involved in the regulation of Notch and Wnt signaling pathways. 